This item was submitted to Loughborough's Research Repository by the author.

Items in Figshare are protected by copyright, with all rights reserved, unless otherwise indicated.

\title{
Transnational academic mobility and gender
}

PLEASE CITE THE PUBLISHED VERSION

http://dx.doi.org/10.1080/14767724.2011.577199

\section{PUBLISHER}

(c) Taylor and Francis

\section{VERSION}

AM (Accepted Manuscript)

\section{PUBLISHER STATEMENT}

This work is made available according to the conditions of the Creative Commons Attribution-NonCommercialNoDerivatives 4.0 International (CC BY-NC-ND 4.0) licence. Full details of this licence are available at: https://creativecommons.org/licenses/by-nc-nd/4.0/

\section{LICENCE}

CC BY-NC-ND 4.0

\section{REPOSITORY RECORD}

Jons, Heike. 2019. "Transnational Academic Mobility and Gender". figshare. https://hdl.handle.net/2134/16201. 


\title{
Transnational academic mobility and gender
}

Heike Jöns

\section{Please cite this paper as follows:}

Jöns, H (2011) Transnational academic mobility and gender, Globalisation, Societies

and Education, 9(2), pp.183-209, ISSN: 1476-7724. DOI:

$\underline{10.1080 / 14767724.2011 .577199}$

\begin{abstract}
This paper examines to what extent the participation of researchers in transnational academic mobility, their experiences and perceived outcomes vary by gender. Based on longitudinal statistics, original survey data and semi-structured interviews with former visiting researchers in Germany, the paper shows that the academic world of female researchers tends to be less international than that of their male colleagues, particularly in the natural sciences. This situation has improved since the 1980s but significant variations remain by source country, subject, career stage and length of stay. The paper argues that the underlying reasons go far beyond direct gender relationships and suggests that conceptualising transnational academic mobility as mobilization processes in Latourian 'centres of calculation' underlines the need for making this experience accessible to the widest possible range of researchers.
\end{abstract}

Keywords academic mobility, gender, geography, knowledge production, higher education, Germany 


\section{Introduction}

In 2000, the European Commission published a report on "Promoting excellence through mainstreaming gender equality" (European Commission 2000). This report was compiled by the European Technology Assessment Network (ETAN) on Women and Science, a group of 14 female senior researchers and policy makers from different EU member states. The report reviewed the situation of women in science and technology and concluded on the basis of an impressive array of statistics that "the under-representation of women threatens the goals of science in achieving excellence, as well as being wasteful and unjust" (p. viii). ETAN's recommendations included the regular provision of gender monitoring statistics, which resulted in the publication of the so-called "She Figures" on gender equality in science and research at an interval of three years (European Commission 2004; 2006; 2009). Providing detailed information on the situation of male and female researchers in the EU, these reports reveal significant variations in the share of female researchers by country, discipline and seniority. Whereas women remain a minority in scientific research in the EU-27 countries (2006: higher education: 37\%; government sector: 39\%; business enterprise sector: 19\%), the most recent report concludes that their "proportion is growing faster than that of men but not enough to indicate that the gender imbalance in science is self-correcting" (European Commission 2009: 16).

Far less is known about gender relations in transnational academic mobility of researchers and academics. This type of people's corporeal movement across national boundaries includes temporary stays abroad for research, learning and/or teaching and is closely linked to other forms of "mobilities central to making and maintaining complex connections in a "networked society"' (Urry 2004: 28), namely the physical circulation of objects, imaginative travel, virtual travel through the internet and 
communicative travel through other person-to-person messages. Transnational academic mobility of researchers, as studied in this paper, mostly resembles circular mobility from the home institution to one or several host institutions. Recent studies have shown that this type of academic mobility can generate significant positive feedback effects for both travelling and hosting academics as well as for their students, research groups and institutions. Examples are the production of new knowledge, the international transfer of existing knowledge, the mobilization of innovative resources for research and teaching, a regular exchange of students and academics, and the establishment of long-term research collaborations (e.g., Altbach 1989; Blumenthal et al. 1996; Welch 1997; Ackers 2005; Van de Sande et al. 2005; Jöns 2007; 2009; Ackers and Gill 2008; Universities UK 2008; O’Hara 2009).

Ackers (2008) provides a compelling criticism of the tendency "to conflate different forms of mobility" and to use "the concept as a proxy for internationalization, excellence and competitiveness" (p. 413), suggesting instead "an assessment that recognizes the value of diverse [mobility] experiences" (p. 433). While this argument clearly advocates a differentiated view on the benefits of transnational academic mobility, she also points out that these movements can shape the career prospects of scientists and "is one means of achieving international research collaboration and knowledge transfer" (p. 432). Equal opportunities of participating in transnational academic mobility are thus crucial for ensuring scientific excellence and efficiency, the latter meaning that the skills of trained male and female researchers are not only used in employment but also potentially enhanced through the experience of other research and teaching contexts. At the same time, there is a need to acknowledge "that not all researchers are equally footloose and that requiring mobility may give rise to discriminatory outcomes" as well (Ackers 2008: 430). 
According to the ETAN report, ignoring gender gaps is to accept discrimination (European Commission 2000: 13) but in the context of improving gender relations at European universities it seems to be important to acknowledge that depending on the spatial, temporal and disciplinary context, these gender gaps may exist in either direction. Based on the resulting need for regular examinations of the situation, this paper aims to provide a comprehensive analysis of gender relations in transnational academic mobility by considering researchers' participation, experiences and perceived outcomes. The study is based on longitudinal statistics from the early 1980 s to the late 2000 s as well as on original survey data and semi-structured interviews examining transnational academic mobility to Germany from 1981 to 2000. The latter two sources focus on research stays of Humboldt research fellows from different countries and disciplines that lasted about one to two years. The Humboldt Research Fellowship Programme, run by the Alexander von Humboldt Foundation (Bonn, Germany), provides a well suited case study because it represents the largest sponsorship scheme for visiting researchers at German universities and research institutions (up to 600 fellowships per year). It also distinguishes itself from more targeted programmes by its openness to applications from all countries and disciplines and the lack of regional and disciplinary quotas for the selection of research fellows.

In the period under consideration, Germany belonged to the Top 5 nations with the highest number of published science and engineering articles worldwide and has risen from the third to the first most important source country for international coauthors of US scientists and engineers (National Science Board 1998; 2010; Adams et al. 2007). As one of the world's leading scientific nations, in which English is the academic language in most subjects of the natural and technical sciences, the country 
receives a representative share of global academic mobility that has been shaped by the countries' specific historical geography of international relations (Jöns 2003a). This study thus allows for tracing gender relations in transnational academic mobility over time that need to be situated within the German context but represent typical trends in academic mobility on a global scale.

The paper is divided into five parts. The first part discusses the research context and introduces a conceptual framework for researching transnational academic mobility. The second part elaborates on the research methodology, whereas the third provides contextual information on the development of gender gaps in both academia and academic mobility by career stage and country. The fourth part presents empirical evidence on gender relations in regard to the researchers' participation in, experiences with and perceived outcomes of academic mobility to Germany and discusses underlying reasons for persistent and changing gender differences. The fifth part concludes by summing up the paper's main findings and outlining their policy relevance.

\section{Research context and concepts}

The transnational circulation of students and academics has increased considerably in the post-WWII period and thus intensified international exchanges in higher education and research (Altbach and Teichler 2001; Robertson 2006; 2010; Bhandari and Blumenthal 2009). Despite the important role of international experiences for academic careers (Musselin 2004; Morano-Foadi 2005; Ackers 2008), few studies discuss gender relations in transnational academic mobility. Notable exceptions include the work by Ackers (2000) on Marie Curie Fellowships in the period 1994 to 1998 that identifies women as 'tied' movers who typically 'follow' a male partner, 
either as a result of prevailing gender roles or out of choice. Research by Leemann (2010: 618) on academic careers of $\mathrm{PhD}$ graduates in Switzerland finds equal chances for male and female post docs "of having spent a research period abroad" within five years after the doctorate but points to fewer international contacts of female post docs and their much smaller chance of finding a supportive mentoring relationship, which both can act as an important barrier for future international mobility and integration.

Aiming to deconstruct eight major myths about the general phenomenon, Welch (2008) feels the need to remind the reader that academic mobility actually displays distinct gender dynamics. He points out that the great majority of American students studying abroad are women (2007: $66 \%$ to $34 \%$ ), while "the opportunity to travel and study abroad actively discriminates against women academics" (Welch 1997: 329). Ackers and Gill (2008) discuss some of the reasons for these imbalances over the life course by exploring the impact of partnering and children on academic mobility. Their findings from qualitative interviews with researchers from Bulgaria and Poland, who had spent at least three months in the United Kingdom and Germany, confirm the great significance of personal and family relationships for academic mobility, either as a barrier or as an incentive. They found that if partnering and parenting hindered migration, this was "likely to have a negative effect on career development, limiting scientists' ability to work effectively and productively" (Ackers and Gill 2008: 232-3). Women were affected by such barriers in particular because compared to their male colleagues more of them were tied to a specific spatial context by private responsibilities and dual-career partnerships. The related negative effects on their career development underline the need for providing women with opportunities for transnational academic mobility despite these barriers. 
This first section discusses the wider context of the scarce research on gender relations in transnational academic mobility. The first part sketches a conceptual framework for researching academic mobilities that responds to Robertson's (2010: 643) call for "alternative concepts and intellectual resources" in order to "move our analyses beyond simple human capital accounts ... and an overly-romantic engagement with movement". The second part reviews existing knowledge on the situation of men and women in science and academia.

\section{Circular mobility and the formation of knowledge centres}

Research stays abroad as studied in this paper are temporary, transnational and mostly but not always related to circular movements from a home institution to one or several host institutions abroad. This is because $80 \%$ of the Humboldt research fellows from 1981 to 2000 returned to their country of origin after the research stays in Germany (Jöns 2007: 100). The temporal nature of their movement results from funding received for conducting a research project of one to two years. This paper is thus interested in temporary but long-term research stays abroad that can be situated between researchers' academic-related short-term travels (e.g., for lecturing, attending conferences, consulting or advancing research collaborations) and their career-related moves for permanent academic posts.

The crossing of international boundaries for research stays abroad is responsible for the transnational nature of this study. In the Humboldt database, the country of origin is documented as the most recent country of academic tenure or place of work and thus might be different to the researchers' country of citizenship. Due to several constellations resulting from these two variables and the possibility that visiting researchers moved on to a third country, this paper speaks of 
'transnational' rather than 'international' mobility, thus capturing the increasingly networked character of highly skilled migration (Jöns 2009: 318).

Research stays abroad are part of a variety of movements involving people, resources and ideas that have been inextricably linked to the growing significance of the 'space of flows' in contemporary global society (Castells 2000). They resemble the circular movement of going out into the world, encountering other people and places, and returning to a home base that Latour (1987) considers being constitutive for knowledge production and the formation of knowledge centres on different geographical scales, from individual researchers via universities to nation states and continental regions (see also Meusburger et al. 2010). Conceptualised as 'cycles of accumulation' in 'scientific centres of calculation', Latour (1987) explains that repetitive circulatory movements from one place to other places have helped to systematically accumulate new and disparate resources in venues such as the university, the archive and the museum. Inside these 'centres of calculation', the gathered resources have been systemized, classified, transformed and combined in order to create new knowledge claims about distant phenomena. Based on the mobilization of scientific resources, the stabilization of knowledge claims, and the successful dissemination of new knowledge beyond its local context of construction, it has been possible for provincial towns (e.g., Palo Alto) and start-up companies founded in a garage (e.g., Hewlett-Packard as the cradle of Silicon Valley) to become knowledge centres dominating many other places at a distance (Latour 1987: 223).

In this paper, I argue that circular academic mobility for research stays abroad can be conceptualised as a twofold mobilization process in Latourian 'centres of calculation', namely the home and the host institutions. This is because the related interactions may be beneficial for both the visiting researchers and their hosts as well 
as for the sending and receiving institutions and countries more generally. Some visiting researchers may stay on in the host country or move to third countries that have joined in to the global mobilisation of talent. As "the borderlines between shortterm mobility, circular mobility, transnational life styles and migration are fluctuating" (Scheibelhofer 2008: 123), a variety of knowledge nodes may eventually benefit from contacts and resources mobilized through research stays abroad.

Those researchers that cannot participate in circular academic mobility for reasons linked to structural inequalities such as an overproportional share of domestic duties are systematically disadvantaged because they miss out on a range of opportunities, including the recruitment of new and unexpected resources for their research and teaching; the validation of their knowledge claims in different academic contexts; the dissemination of their research findings to an international audience; and the establishment or deepening of professional contacts. All these activities may be useful for the researchers' work and professional careers and may also generate positive feedback effects for their students, research groups and institutions (Latour 1987: 210). Expressed in Bourdieu's (1986: 242) terms, travelling researchers have the possibility to exchange and accumulate different forms of capital that are "determining the chances of success for practices" and provide access to further capital, including prestige (symbolic capital), education and knowledge (embodied cultural capital), books and research infrastructure (objectified cultural capital), academic credentials and qualifications (institutionalised cultural capital), a network of relationships (social capital), and economic capital that is directly convertible into money. The potential for generating unforeseen inspiration, professional networks, and cumulative knowledge production processes through circular academic mobility 
thus explains in conceptual terms why this experience needs to be made accessible to the widest possible range of researchers, including a fair balance of gender.

\section{The situation of men and women in science and academia}

For addressing gender differences in the global circulation of researchers, the paper draws on rich work about the situation and careers of men and women in science and academia that have mostly been examined in the United States (e.g., Zuckerman 1987; Zuckerman et al. 1991). Among the main topics addressed in the literature are academic career progression of men and women (Aanerud et al. 2007; Ginther and Kahn 2006; Loeb 2006; Shaw et al. 2007); career mobility of male and female academics in national higher education systems (Shauman and Xie 1996; Kulis and Sicotte 2002); gender differences in academic pay, productivity and performance (Loeb 2006); and challenges of combining work, motherhood and family (Cole and Zuckerman 1987; Ward and Wolf-Wendel 2004). These studies show that similar to the European experience (European Commission 2009), the situation of women in US higher education has considerably improved over the past decades but that women remain strongly underrepresented in senior academic positions, at research intensive institutions, and in the natural and technical sciences. Women are also disadvantaged by a distinct gender pay gap that has remained quite persistent over the past decades, while the gender gap in academic productivity and performance has narrowed and even disappeared in fields with a high share of women (Loeb 2006). Recent studies suggest that the underrepresentation of women in tenured academic positions and full professorships in the life sciences, the physical sciences and engineering can be attributed to fertility decisions rather than gender differences in promotion, but that in the social sciences and to some extent in the humanities women are disadvantaged in 
promotion to tenure (Ginther and Kahn 2006). Aanerud et al. (2007: 119) explain this as follows: the higher the proportion of women in a given field and the fewer the "labor market alternatives to tenure-track and tenure positions, the more the gender tenure ratio favors men."

Evidence on the differential impact of marriage and children on male and female academics suggests that marriage and children hinder women's career progression beyond the early post-doc years, while enhancing men's likelihood of advancing their academic careers (Xie and Shauman 1998; Ginther and Kahn 2006). While Loeb (2006), in her review of the existing literature, cautions that the effects of family status on academic productivity and performance are not entirely clear, she sums up these major trends: married academics seem to be more productive than unmarried academics; young children have a negative effect on women's but not on men's productivity; married tenure-track men spend more time on research and work more hours than married tenure-track women who spend significantly more time on household labour and - in the presence of children at home - on childcare. Nevertheless, the quality of scholarship is about the same "but there are indications that the evaluation of scholarship and other performance measures may be biased, with judgments of women's work harsher by both men and women, especially when the knowledge of an individual's work is fairly cursory" (Loeb 1996: 177).

These findings suggest that women in US higher education are structurally disadvantaged in the sense that the expectations about their contribution to domestic labour, childcare and research tend to be higher than that of men, which is reflected in corresponding practices. For this study this means that participation in transnational academic mobility starts from an unequal standing of men and women in science and 
academia, at least in the United States that worryingly, as explained below, is one of the most advanced countries in regard to gender equality.

\section{Research methodology}

Aiming to contribute to a growing body of work on gender relations in academic mobility, this paper combines quantitative and qualitative data on male and female visiting researchers from different countries and disciplines. The first aim is to outline typical situations and wider trends with regard to gender relations in transnational academic mobility, to discuss how these changed over time, and to position individual perspectives within the bigger picture. The second aim is to produce new knowledge on the performance of men and women during research stays abroad. In regard to the role of accompanying partners and children, the focus will be on heterosexual relationships as the dominant form of partnering among visiting researchers to Germany in the 1980s and 1990s. The whole diversity of heterosexual and homosexual forms of partnering and family life is covered by the overall argument that gender imbalances in academia are context-dependent, could be the other way around, and thus go far beyond direct gender relationships. The focus on heterosexual relationships solely results from the nature of the empirical material that did not contain any references to same sex partnerships.

The study applies a mixed-methods approach by analyzing three different sets of data that complement each other. First, secondary statistics compiled by the European Commission (2000; 2009) and the Institute of International Education (2005; 2010) are used to contextualize academic mobility to Germany within changing gender relations in both academia and global flows of students and 
academics. The focus on international student and staff mobility to the United States since the 1980s results from the availability of suitable contextual data.

Second, data resulting from an own postal survey conducted among former Humboldt research fellows who stayed in Germany from 1954 to 2001 informs the main part of the analysis. Based on an overall response rate of $51 \%$, or 1,893 questionnaires, the paper analyzes 1,131 responses of those researchers who started their first Humboldt research stay in the years 1981 to 2000. This equals the responses of every 9th Humboldt research fellow in the 1980s and slightly more than every 8th in the 1990s (Table 1). Chi-square tests were used to examine statistically significant differences between men and women in terms of immediate and long-term results of their Humboldt research stays in Germany (Tables 2, 3 and 4). The potential gender differences were explored in total, by decade (1981-90, 1991-2000), by broad subject area (natural sciences, engineering, social sciences and humanities), and by type of entourage to Germany (by themselves, with partner, with family - i.e. partner and children -, with children). All statistically significant results on the 95\%-level and above are discussed in this article but striking statistical trends below the 95\%threshold are also addressed. Qualitative responses to the final open question of the questionnaire inform the analysis as well, including remarks of research fellows who first came to Germany from 1980 to 2001 .

[Please insert Table 1 about here]

The third data source is provided by 82 semi-structured interviews with former visiting researchers. 21 of these interviews were conducted with Humboldt research fellows (designated as STP in interview citations) who came to Germany from 
different countries than the United States but worked there in 2003, mainly at Harvard University, the University of Chicago, and the University of California at Berkeley (UCB). This constellation was chosen in order to capture the motivations and experiences of visiting researchers from a range of countries, while saving travel costs and elaborating on the researchers' US perspective as well. At the time of their research stay in Germany, they were mostly post-docs and professors up to 40 years of age. The gender proportion in this interview sample was $71 \%$ men (15) and $29 \%$ (6) women. The other 61 interviews were conducted with Humboldt award winners from the United States (designated as PRT in interview citations) who were senior scientists with past achievements when spending an extended research stay at German universities and research institution between 1972 and 1996. At the time of the interview, they still worked at their home institutions in the Boston and San Francisco Bay areas, including Harvard University, MIT, and UCB. Due to the seniority of Humboldt award winners, their prestigious home institutions (72\% of US award winners 1972-96 worked at Carnegie R1 universities, i.e. the 50 leading US research universities; see Jöns 2003b: 251), and a concentration on the natural and technical sciences in the first ten years of this scheme, few female researchers participated in the Humboldt Award Winner Programme during the first 25 years of its existence (1972-96: 1.6\%). None of these women was left in the actual interview sample (the female award winner cited below was interviewed in Germany) but some of the 61 male interviewees are cited in this paper to support the argument that they also faced issues with schooling of children, double-career partnerships and caretaking of relatives that complicated, hindered or postponed transnational academic mobility.

In sum, the mixed-methods approach draws on unique long-term data sets that allow for a comparison of gender relations in transnational academic mobility over the 
past three decades, the documentation of gender relations in regard to long-term effects of research stays abroad, and the discussion of different perceptions and experiences of individual researchers in the sciences and the arts and humanities.

\section{Gender gaps by career stage and country}

The regularly published EU reports on gender equality in science identified significant gender gaps at the advanced stages of an academic career. The underrepresentation of women among professors has improved over the past decades but considerable variations remain between countries (Figure 1). In 1997, some EU member states such as the United Kingdom and Germany had nearly achieved a gender balance at the level of undergraduate students, and in France female students even slightly outnumbered male students, but the number of women dropped significantly at each progressive career stage, leading to a considerable gender gap in the most senior positions, the full professorships. Ten years later, in 2007, the situation of female academics had improved in all three countries. Impressive progress was made in the United Kingdom where the shares of female academics caught up with the quite positive gender relation in France. Both countries are now approaching the situation in the United States, where equal employment legislation introduced in the 1970s has contributed to a fairly progressive attitude towards gender equality (Loeb 2006). Among associate professors in the United States, there is a split of $60 \%$ men and $40 \%$ women but a much larger gap still exists among full professors. The latter is even more distinct in Germany, a country with "one of the lowest levels of female participation in higher education and on the academic labor market in Europe" (Majcher 2002: 6). The reasons for this situation and its impact on the experiences of female visiting researchers in Germany will be discussed below but the 
immediate question arising from this contextual data is how these gender relations change when it comes to participation in transnational academic mobility.

[Please insert Figure 1 about here]

Longitudinal data on transnational academic mobility are provided by the Open Door statistics of the Institute of International Education in the United States. The development of student and scholar mobility to the United States over the past three decades constitutes an important frame of reference for academic mobility of researchers to Germany as the United States have been the most attractive country for international students and scholars in the second half of the $20^{\text {th }}$ century (OECD 2009). In the case of international student mobility to the United States, a gender balance has almost been achieved in 2005/06, even though the situation may have varied significantly by source country. The increasing share of female visiting students went hand-in-hand with a growing share of singles that has reached almost $90 \%$ today, thus reflecting a growing age at first marriage and an important link between academic mobility, gender and relationship status (Figure 2a; students with partners/children rarely engage in study abroad, see Teichler and Maiworm 1997).

[Please insert Figure 2 about here]

At the level of international scholars in the United States, the gender gap has been closing as well but with a time lag when compared to students (Figure 2b). In $2008 / 09$, the gender ratio amounted to $65 \%$ men and $35 \%$ women, which shows that the $60 \%$ to $40 \%$ split achieved among international students in $1996 / 97$ has not been 
matched among international scholars more than a decade later. As the share of women in academia has considerably improved in many countries around the world over these twelve years, this data supports the view that women face greater barriers for participating in transnational academic mobility than their male colleagues.

\section{Engaging in transnational academic mobility to Germany}

The secondary data on the United States as a host country for international students and scholars thus reveals a positive trend in terms of a shrinking gender gap - for international students since the mid-1980s and for international scholars since the late-1990s. Nevertheless, the gender gap in academic mobility to the United States remains significant at more advanced stages of an academic career, and there will certainly be important differences between source countries and disciplines. This section will explore these issues in more depth by shifting the focus to Germany as a host country for visiting researchers and academics. The guiding research question is to what extent participation in transnational academic mobility and the visiting researchers' experiences and perceived outcomes varied by gender. The statistical analysis will compare gender relations in total and in regard to different countries, decades, subject areas, and types of entourage to Germany.

\section{Participation}

The Humboldt Research Fellowship Programme was established in 1953 to enable highly qualified researchers up to 40 years of age and from all countries and disciplines to conduct a research project in Germany for a period of one to two years (Jansen 2004). With almost 9,500 sponsored visiting researchers and academics from 1981 to 2000 - these were 400 to 500 new Humboldt research fellows per year - it has 
been the most significant sponsorship programme for long-term research stays of international scientists and scholars at German universities and research institutions. The average age of Humboldt research fellows from 1981 to 2000 was 35 years; most of them were research fellows/post-docs (22\%), assistant lecturers/instructors (17\%), assistant professors (19\%) and associate professors (22\%), some were full professors $(6 \%)$ or held a research post outside of the university (8\%).

The underrepresentation of women in the Humboldt Research Fellowship Programme was more distinct than in the case of international scholars going to the United States (1981-90: 12\% women; 1991-2000: 17\% women; see Table 1). This situation can partly be attributed to the length of the stay involved as the Humboldt Research Fellowship Programme has funded long-term research stays with an average length of eleven months plus an average extension of six months (1981-2000), whereas the data on international scholars in the United States includes short-term stays as well. As this study will show, long-term research stays abroad are much more difficult to realize than shorter stays, particularly in regard to the question of whether a partner and children should also relocate to the host country and if so, for how long.

\section{[Please insert Figure 3 about here]}

\section{Type of entourage}

In heterosexual relationships, the temporary relocation to a different country with the whole family tends to be easier for men than for women. This is indicated by the research fellows' type of entourage to Germany: in the 1980s, $60 \%$ of the female visiting researchers came to Germany on their own, while $60 \%$ of the male researchers relocated to Germany with their family (Figure 4a). This asymmetry in the 
type of entourage to Germany - only every fourth woman was accompanied by a family - can largely be explained by traditional gender roles and family patterns based on the idea of the male 'breadwinner'. For career mobility in the United States, Shauman and Xie (1996) have shown that the presence of children limits female scientists' migration significantly more than that of male scientists because of their greater responsibility for child care (see also Aanerud et al. 2007). Women are also less likely to be married than men when pursuing a career in academia, and women scientists are more likely to be married to other academics and highly educated professionals (Kulis and Sicotte 2002: 2). Women with partners are thus strongly affected by the implications of double-career relationships that complicate participation in transnational academic mobility much more than single-career relationships (Ackers 2000).

[Please insert Figure 4 about here]

In the 1990s, the highly asymmetric patterns of entourage during a research stay in Germany slightly decreased (Figure 4b). Many more women were accompanied by their partner but still only every fourth female visiting researcher was accompanied by a family compared to more than every second in the case of men. A 38 year-old Humboldt award winner from Stanford University who worked in the field of chemical engineering spent one year at the Technical University in Munich in 1998 together with her husband, two children at the age of two and four and an aupair, who looked after the children. This was mainly possible because her husband worked in the IT business and only needed a laptop and access to the internet for his daily work, which demonstrates that these cases are rather unusual. 
Even if men were frequently accompanied by their wife and children, some of them had also been affected by complex considerations about taking sabbaticals abroad. One of the interviewees postponed his sabbatical because his wife had to take care of her parents:

[My host] was asking me why don't you come over, why don't you come over, and I said well, I would really love to but there were certain family constraints, we could not go, my mother in law was living with us, she had a heart condition and we could not leave her alone. She died in 1988, and then that impediment was removed, so [my host] then arranged for this Humboldt award. (PRT-1, first Humboldt research stay in 1992, Engineering)

Another interviewee had spent his first two sabbaticals in Germany and a third one at home before postponing a fourth sabbatical for several years as a result of living in a double-career partnership:

[N]ow I'm married so it's not like I can just go wherever I want, and my wife has a very important job here ... she works in a bio-tech company, and she can't just pull up and go somewhere for six months, so I probably will take a sabbatical next year and we've been thinking about where I'm going to go on my sabbatical, we have no idea, so whether it's some place in the States so it's not too far away from here, or whether it's across the bay. (PRT-36, first Humboldt research stay in 1988, Bio Sciences) 
Arranging a long-term research stay abroad thus involves complex considerations for both men and women but due to traditional gender roles and family patterns as well as their frequent double-career relationships female researchers tend to be more restricted in their transnational movements than male colleagues.

The section on 'Experiences and academic outcomes' will analyze whether the statistically significant gender differences in regard to the type of entourage to Germany impacted on the researchers' academic interaction and productivity during the research stay and on their subsequent interactions with colleagues in Germany.

\section{Source countries and disciplines}

Gender relations in transnational academic mobility to Germany considerably varied by source country (Figure 5). In the two most frequent source countries from 1981 to 2000, the United States and China, the share of female research fellows amounted to $18 \%$ and $8 \%$ respectively. This difference might be partly linked to a much greater emphasis on the social sciences and humanities among research fellows from the United States (33\%) than from China (6\%), but a correlation analysis on all countries reveals no linear relationship between subject emphasis and share of female research fellows. This suggests that the latter remains strongly influenced by "culturally embedded perceptions of gender roles" (Majcher 2002: 20) and existing professional and private support networks for female researchers. In the 1990s, Denmark and Portugal achieved a 50\% balance of male and female research fellows, while $40 \%$ of research fellows from France and Spain were female. This shows that women do not need to be underrepresented in transnational academic mobility. According to the ETAN report, Portugal, Spain and France had the highest share of female associate professors in Europe (1997: c. 35\%), while Denmark's share of women among 
Humboldt fellows more than doubled their share among associate professors (19\%; see European Commission 2000: 10).

[Please insert Figure 5 about here]

Subject-specific gender imbalances in transnational academic mobility reflect horizontal gender segmentations in the academic labour market. This is because the underrepresentation of women in the natural sciences and even more so in engineering went hand-in-hand with much lower participation rates of female visiting researchers than in the social sciences and humanities (Figure 6). From the 1980s to the 1990s, the share of women among Humboldt research fellows rose in all three subject areas and in many countries such as the United States. Compared to the share of women among US post-docs, assistant and associate professors, the share of female research fellows was much lower, which confirms that transnational academic mobility is more difficult to realize for women than for men.

\section{Academic hosts and gender-related affinities}

Most strikingly, women were not only underrepresented among the mobile researchers. Even among the academic hosts of research fellows, who were professors in Germany providing logistical and intellectual support for the visiting researchers and often collaborating with them as well, women accounted for a much lower share than among German professors in total (1991-2000: 3\% female hosts, 9\% female professors; see Figure 6). This imbalance was even larger in the Award Winner Programme whose academic hosts and visiting researchers displayed a greater seniority than those involved in the Fellowship Programme (1972-96: 1\% female 
hosts, 7\% female professors; see Jöns 2003b: 237). In both examples the extent of the gender imbalance is surprising as there is no mobility involved in hosting a visiting researcher. Therefore, the underrepresentation of female professors among academic hosts suggests that the professional world of female professors tends to be less international than the professional world of their male colleagues.

Based on the finding that "academic mobility is as often the consequence of transnational knowledge networks as the creator of new academic linkages" (Jöns 2009: 334), this can most certainly be regarded as a direct result of women researchers' lower participation rates in transnational academic mobility at advanced career stages. Among the Humboldt research fellows 1981-2000, $72 \%$ of the female researchers had lived abroad for at least one month before the Humboldt research stay in Germany, while this was only true for $57 \%$ of the men. After the research stay and thus at more advanced career stages, $48 \%$ of the women and $53 \%$ of the men lived abroad for at least another month. This distinct shift in transnational flexibility during the academic careers of men and women is statistically significant in both decades. The trend can also be observed below the level of statistical significance in the natural sciences, the social sciences/humanities and in regard to all four types of entourage, which supports the argument that women tend to be more affected than men by placebinding private responsibilities after the average age of 35 (Diehl 2004 cited in Ackers and Gill 2008: 92 identifies a distinct overrepresentation of mobile men in the age group 30-49). The difference between men and women in regard to conducting further long-term research stays abroad is smallest and almost balanced among those who came to Germany with a family (women: $52 \%$; men: $53 \%$ ). These women not only seemed to be in a good position to engage in long-term transnational academic mobility, but they will also have made positive experiences with relocating to 
Germany for a limited period of time. The difference is largest among those who came to Germany with a partner, which indicates that these women may have postponed having a family until after they gathered international working experience and secured a permanent job (women: $38 \%$; men: $56 \%$; by themselves: women: $45 \%$; men: 50\%; see also Ackers and Gill 2008: 233 on 'fertility solutions').

The underrepresentation of female academic hosts is thus an expression of the conceptual argument that a reduced participation in circular academic mobility is inextricably linked to fewer opportunities for international networking and for generating related cumulative feedback effects for one's work and career. Due to the prevailing structural discrimination of female researchers during their mid-career stages, they tend to be less well internationally networked than their male colleagues at advanced career stages and thus are not only less often chosen as academic hosts by prospective visitors (who often have met their hosts before) but are also less inclined to arrange such research stays as a consequence of existing international linkages.

Since female professors hosted twice as many female (1981-2000: 31\%) than male research fellows (14\%), a gender-related affinity between guests and hosts also seems to influence transnational academic mobility for long-term research stays abroad. In the Award Winner Programme, female professors nominated even five times more women for the award (1972-96: 11\%) than their male colleagues (2\%; see Jöns 2003b: 236). These findings suggest that common experiences of female socialization may provide a valuable basis for a rewarding scientific and scholarly exchange. They also fit the picture of a similar gender bias in citation practices (Ferber 1986). Therefore, it can be argued that an underrepresentation of women in academia, and in leading academic positions in particular, impacts on the share of female visiting scientists and scholars. More female academic hosts would most likely 
result in more female visiting researchers and thus not only benefit their scientific accumulation processes but also guarantee a greater heterogeneity in knowledge production by helping to move beyond prevailing 'male tales' (Traweek 1988).

[Please insert Figure 6 about here]

\section{Experiences and outcomes}

The final question to be raised is whether there are any systematic differences between male and female visiting researchers in regard to their academic interaction and productivity in the host country and the long-term effects of their research stays. Most importantly, there are no statistically significant differences between male and female research fellows when comparing their scientific interaction at the host institution during the research stay; their perceived integration into research and teaching in Germany; the types of resulting publications; and the number of resulting events (conferences, workshops, seminars) organized with researchers in Germany (Table 2). In regard to all these aspects, there are also no statistically significant differences between men and women by decade, subject and type of entourage, which shows that there is no gender gap in terms of academic performance during a longterm research stay abroad.

The type of entourage to Germany also does not directly impact on academic output. In terms of resulting publications, however, it is important to note that the questionnaire inquired whether single-authored and different types of co-authored publications resulted from the research stay. It did not ask about the number of resulting publications, which might provide a different picture and therefore requires more research. Kulis and Sicotte (2002: 4-5), for example, cite studies showing that 
"married women publish more than single women"; other studies revealed that women with academic partners publish more than women with nonacademic partners, while the reverse is found for men (Astin and Milem 1997). It is therefore possible that that the type of family status and entourage during transnational academic mobility may impact on the number of resulting publications if not on the type of resulting publications. This point is supported by the finding that below the defined level of statistical significance, men organized more frequently at least two resulting events than women (19\% to $14 \%)$. This difference was most distinct among those who came to Germany on their own (20\% to $10 \%)$ and irrelevant for those who came to Germany with their family ( $21 \%$ to $20 \%$ ) or partner (15\% to $13 \%)$, thus hinting at subtle influences of relationship status and type of entourage on academic output resulting from transnational academic mobility that match some of the cited findings on gendered publication behaviour in academia more generally.

\section{[Please insert Table 2 about here]}

\section{Gender discrimination in the natural sciences?}

Continued scientific interaction between visiting researchers and colleagues in Germany after the research stay did not vary significantly by gender when compared in total and in the social sciences and humanities (in engineering the number of women was too small for conducting meaningful statistical tests). The same applies to return visits by the visiting researchers themselves. In the natural sciences, however, statistically significant differences existed in both cases (Table 3): 60\% of male natural scientists engaged in occasional or regular collaboration with colleagues in Germany after the research stay but this was only the case for $41 \%$ of the female 
natural scientists. Also, about $44 \%$ of the men returned for a further long-term stay of over one month to Germany but only $32 \%$ of the women did. Even in terms of shortterm return visits of up to one month, significantly more male natural scientists returned to Germany than female natural scientists (47\% to $32 \%)$. The data suggests that this is not only related to asymmetrically distributed family obligations at later career stages but also to a difficult integration of women in the male-dominated natural sciences. The problematic impact of the prevailing academic culture in the socalled 'hard sciences' on female researchers has been discussed in feminist science studies by scholars such as Harding (1986) and Traweek (1988), and it is also expressed in the following comment:

As an Indian woman Humboldt fellow, I faced a severe handicap in terms of openness in scientific discussions. To prove my credibility as a scientist and the seriousness towards my work was often a problem. (STP survey, response to open question, first research stay in 2001, Chemistry)

Her experience fits the picture drawn by a female research fellow from 1986, which suggests that in the intermediate decade not much progress was made with respect to the standing of women in some places and disciplines of German academia:

The only negative side of my stay concerned interactions with officials, who were none too friendly to foreigners at that time, and the attitude towards women in academia, which were very backwards in comparison not only to the USA but also to other countries where I had studied and done research, 
such as France and Great Britain. (STP survey, response to open question, first research stay in 1986, History)

\section{[Please insert Table 3 about here]}

Along these lines, the research stays' importance for the fellows' research work was significantly better evaluated by men than by women in the $1980 \mathrm{~s}$, in the natural sciences, and among those who came to Germany on their own (Table 4). This means that from the perspective of the majority of women the reception of female researchers in Germany had actually improved from the 1980s to the 1990s but that the working environment in the natural sciences could be much more favourable for women, particularly for those travelling on their own. While these trends over time and the differential acceptance of women across disciplines and in regard to varying relationship statuses are certainly reflective of female researchers' experiences in a number of host countries around the world, the particular German context requires brief consideration in order to position this case study in regard to the variety of situations in other host countries and to highlight the complex interdependencies between national structures of academic career progression, gender relations and the attractiveness of national research contexts for visiting researchers as well as for foreign academics seeking permanent positions abroad.

[Please insert Table 4 about here] 


\section{Gender discrimination in German academia?}

In the 1980s and 1990s, visiting researchers in Germany entered an academic context in which the participation of women was relatively low, particularly in comparison to other European countries and the United States. This not only influenced women's experiences with German academia but can also be regarded as an impediment for attracting further women researchers to Germany due to the lack of female academic hosts. All these aspects are still relevant today as Germany remains - despite recent progress - among the countries with the lowest share of female professors in Europe. Majcher (2002: 15) summarizes the situation as follows:

Women's position in [German] academia could best be described in terms of subordination, marginalization and segregation. Women's career paths and career outcomes differ from men's. This is related to women's life cycle (motherhood), segmentation of the academic labor market, institutional context (availability of childcare, organization of work, inclusion or exclusion from informal networks) and finally, gender discrimination.

Traditional family patterns and gender roles are firmly anchored within German society and thus seem to be particularly resistant to change:

West Germany, in contrast to e.g. France, developed a welfare regime based on a conservative male-breadwinner family model, strongly supported by value systems and traditional gender roles. As a result, German welfare regulations used to offer little incentives for an egalitarian family model. At 
the time, the promotion of women on the labor market and childcare facilities was hardly a social policy priority. (Majcher 2002: 20)

One of the greatest problems for both male and female academic careers in Germany is the structure of academic positions characterized by a significant gap between being an assistant to a professor and becoming a professor oneself (Musselin 2004). The Habilitation, a postdoctoral qualification often still required for applications to permanent academic posts, has tied young scientists and scholars to the research group of a professor for many years beyond the $\mathrm{PhD}$. This has led to great job insecurity as it remains uncertain whether one will be able to secure a professorship at the age of about 35 to 45 and if so, where in the country this will be. Recent reforms of German higher education have introduced junior professorships in the form of sixyear tenure-track positions but the possibility of promotion in one institution from junior professor to one of the two main permanent academic posts, W2- and W3professorships, or even from W2- to W3-professorships are not part of this agenda. Promotion at the professorial level still requires the application to professorships at other institutions and might only be realized via mobility from one university to another (Meusburger and Schuch 2010). This complicates important periods of the life cycle such as raising children and thus explains a considerable part of the significant drop-out of women on the way towards senior academic positions.

From the perspective of transnational flows of academics, this inflexible structure of academic positions also discourages foreign academics from taking up permanent posts in Germany, a fact that is highly problematic in an era in which foreign academic staff and their international networks have been identified as an important asset in countries such as the United Kingdom (Universities UK 2007). In 
2006, 19\% of academic staff at UK universities were non-UK nationals (Universities UK 2007: 2) but the equivalent share at German universities reached only $10 \%$ (DAAD 2008). In turn, Germany is the most important source country for non-UK academic staff working in UK universities (ahead of Ireland, USA, China and Italy; see Universities UK 2007). This can mainly be regarded as a result of an attractive UK environment for research and teaching and a lack of 'tenure-track' positions in Germany (Hoyler and Jöns 2008). Therefore, the Bologna process that recently introduced internationally compatible degree programmes at German universities might usefully be extended to academic career structures in order to promote transnational career progression, to improve the situation of women in German academia, and thus to encourage more female scientists and scholars from abroad to conduct their research at German universities and in collaboration with colleagues working there, either as visiting researchers or as permanent professors.

\section{Concluding remarks}

This paper has examined gender differences in a specific form of transnational academic mobility, namely temporary and mostly circular movements of researchers from their home to one or several host institutions that are part of an increasing global circulation of highly skilled professionals. The paper has offered a conceptual framework for researching transnational academic mobilities by conceptualising these movements as twofold mobilization processes in Latourian 'centres of calculation', involving a number of actors and institutions at the sending and receiving ends. This framework explains the need for equal opportunities in the access to transnational academic mobility by the potential cumulative benefits for a researcher's international networks, academic work and professional career. 
The paper has focussed on the participation in, experiences with and perceived outcomes of transnational academic mobility by analyzing research stays of Humboldt research fellows and award winners in Germany from 1981 to 2000. Based on a mixed-methods approach using longitudinal statistics, own survey data and semistructured interviews, the analysis produced seven findings on the gender dimension in transnational academic mobility that need to be situated within the German context but contribute to a better understanding of existing imbalances, wider trends and underlying reasons on a global scale.

First, this paper has identified several gender gaps in transnational academic mobility, thus suggesting that the academic world of female researchers tends to be less international than that of their male colleagues, particularly in the natural sciences. Female academics are underrepresented in circular academic mobility and, in the natural sciences, also in continued interaction with colleagues in the host country after the research stay abroad. These findings extend the relevance of studies showing that female scientists are typically less geographically mobile than their male counterparts from the national (e.g., Kulis and Sicotte 2002) to the transnational scale.

Second, at earlier career stages and a younger age, female students and researchers tend to be equally and sometimes more internationally mobile than male students and researchers but at advanced career stages and beyond the average age of 35 women researchers' flexibility to relocate internationally for more than one month decreases much more than that of their male colleagues. These gendered patterns of mobility over the life course confirm findings of previous studies (e.g., Ackers 2000; Leemann 2010) and can largely be attributed to prevailing traditional family patterns and gender roles in which domestic work, including the care for children and the elderly, predominantly resides on the shoulders of women (see also Scheibelhofer 
2008). Although men are also increasingly affected by mobility constraints resulting from dual-career relationships, gendered patterns of partnering and household labour are the main reasons for why most female researchers still face greater barriers for participating in transnational academic mobility than their male colleagues.

Third, the types of entourage during the research stay abroad are also highly gendered. This mostly hidden dimension is again linked to differential relationship patterns of male and female academics (Kulis and Sicotte 2002) and results in the majority of men being in the favourable situation of moving abroad with their whole family. The type of entourage did not directly impact on the visiting researchers' academic output but evidence suggests the existence of subtle influences of relationship status and type of entourage on academic output that tend to disadvantage women more than men but require further research.

Fourth, the analysis has shown that female participation in transnational academic mobility has considerably improved since the 1980s but that significant variations continue to exist by source country, subject, career stage and length of stay. Denmark, Portugal, France and Spain are European countries that achieved very positive gender relations in the 1990s, thus showing that women do not need to be underrepresented in academic mobility. The situation of female visiting researchers was also much better in the social sciences and the humanities than in the natural sciences, while female visiting researchers in engineering were even too rare for drawing meaningful conclusions beyond this striking gender gap.

Fifth, compared to their growing presence in academia, women were not only underrepresented as participants in transnational academic mobility but also as academic hosts of visiting researchers. For the reasons outlined above, longer-term research stays at advanced career stages were much more difficult to realize for 
women than for men, which restricted the opportunities of female professors for establishing and maintaining international networks and for generating cumulative knowledge production processes through circular academic mobility. If affected by this structural discrimination, female professors were less often chosen as academic hosts and also invited fewer researchers as a result of existing international linkages.

Sixth, based on the finding that female professors hosted a higher share of women than their male colleagues, the paper has argued that more female professors would not only result in a higher share of female visiting researchers but also improve their experiences in the host country. Further research needs to be done on the importance of gender bonding between visiting researchers and academic hosts and of gender-specific role models in transnational academic mobility more generally.

Seventh, the study highlighted that there is no gender gap in terms of academic performance during a long-term research stay abroad. In regard to continued scientific interaction and return visits after the research stay, statistically significant gender differences were found in the natural sciences. Personal experiences and less enthusiastic evaluations of the research stays' importance for their own research support the impression that a few female natural scientists became not only restricted in their transnational flexibility after the research stay but experienced difficulties with the integration in a male-dominated research environment in the natural sciences.

Although this paper has focused on transnational academic mobility in the 1980s and 1990s, the conclusions drawn from the analysis are highly relevant to current science policies. First, the long-term effects of these research stays are still being produced today as most of the former research fellows are still professionally active. Second, despite some progress over the past decades, Germany remains one of the countries with the lowest share of female professors in Europe. In regard to 
Germany as a host country, three developments seem to be desirable for removing remaining 'glass ceiling' effects and improving transnational academic relations: first, a fundamental change of attitudes towards traditional gender roles and women in leading positions in the labour market, including academia; second, appropriate measures for improving professional support networks such as mentoring programmes (Harris 2007) and sufficient child care facilities from a very young age onwards (Majcher 2002); third, a reform of 'tenure-track' and career progression opportunities in academia, not only directly after the $\mathrm{PhD}$ (in a different institution) but also between different types of professorships in one institution. Drawing upon Musselin's (2004: 72) work, “building a more harmonised academic labour market in Europe" does not only require comparable degree programmes but also compatible career paths in order to remove "formal, cognitive and structural differences that exist between the various national academic labour markets" and continue to complicate transnational academic mobility of researchers for temporary and permanent positions - even within Europe.

\section{Acknowledgements}

The final version of this article benefitted from comments by Heike Alberts, Liz Mavroudi and two anonymous referees that I gratefully acknowledge. It is based on a research project funded by the German Research Council and led by Peter Meusburger (DFG-Projekt ME 807/18-1). I also wish to thank the Humboldt Foundation for supporting the project and Anita Schlögl for her comments on this paper. The views expressed in this article and any errors are solely my responsibility. 


\section{References}

Aanerud, R., Morrison, E., Homer, L., Rudd, E., Nerad, M. and Cerny, J. 2007. Widening the lens on gender and tenure: looking beyond the academic labor market. NWSA Journal 19, no. 3: 105-123.

Ackers, L. 2000. The participation of women researchers in the TMR Marie Curie Fellowships.

ftp://ftp.cordis.europa.eu/pub/improving/docs/women_final_rpt_3march2000. pdf, accessed on $7^{\text {th }}$ June 2010 .

Ackers, L. 2005. Moving people and knowledge: scientific mobility in the European Union. International Migration, 43, no. 5: 99-131.

Ackers, L. 2008. Internationalisation, mobility and metrics: a new form of indirect discrimination? Minerva 46: 411-435.

Ackers, L. and B. Gill. 2008. Moving people and knowledge: scientific mobility in an enlarging European Union. Cheltenham: Edward Elgar.

Adams, J., Gurney, K. and Marshall, S. 2007. Patterns of international collaboration for the UK and leading partners. Leeds: Evidence Ltd.

Altbach, P.G. 1989. The new internationalism: foreign students and scholars. Studies in Higher Education 14, no. 2: 125-36.

Altbach, P.G. and Teichler, U. 2001. Internationalization and exchanges in a globalized university. Journal of Studies in International Education 5, no. 1: $5-25$.

Astin, H.S. and Milem, J.F. 1997. The status of academic couples in U.S. institutions. In Academic couples: problems and promises, ed. M.A. Ferber and J.W. Loeb, 128-155. Urbana: University of Illinois. 
Bhandari, R. and Blumenthal, P. 2009. Global student mobility: moving towards brain exchange. In Higher education on the move: new developments in global mobility, ed. R. Bhandari and S. Laughlin, 1-15. New York: Institute of International Education.

Blumenthal, P., C.D. Goodwin, A. Smith and U. Teichler. ed. 1996. Academic mobility in a changing world. London: Jessica Kingsley Publishers.

Bourdieu, P. 1986. The forms of capital. In Handbook of theory and research for the sociology of education, ed. J.G. Richardson, 241-258. New York: Greenwood Press.

Castells, M. 2000. The rise of the network society. 2nd edition. Oxford: Blackwell.

Cole, J.R., and Zuckerman, H. 1987. Marriage, motherhood and research performance in science. Scientific American 255: 119-125.

DAAD. ed. 2008. Wissenschaft weltoffen 2008: facts and figures on the international nature of studies and research in Germany. Bielefeld: Bertelsmann.

European Commission. ed. 2000. Science policies in the European Union: promoting excellence through mainstreaming gender equality: a report from the ETAN Expert Working Group on Women and Science. Luxembourg: Office for Official Publications of the European Communities.

European Commission. ed. 2004. She figures 2003: women and science statistics and indicators. Luxembourg: Office for Official Publications of the European Communities.

European Commission. ed. 2006. She figures 2006: women and science statistics and indicators. Luxembourg: Office for Official Publications of the European Communities. 
European Commission. ed. 2009. She figures 2009: statistics and indicators on gender equality in science. Luxembourg: Publications Office of the European Union.

Ferber, M.A. 1986. Citations: are they an objective measure of scholarly merit? Signs: Journal of Women in Culture and Society 11, no. 2: 381-389.

Ginther, D.K. and Kahn, S. 2006. Does science promote women? Evidence from academia 1973-2001. NBER Working Paper No. 12691. Cambridge, MA: National Bureau of Economic Research.

Harding, S.G. 1986. The science question in feminism. Milton Keynes: Open University Press.

Harris, B.J. 2007. Women's future in higher education: directions for future research. NWSA Journal 19, no.3: 15-22.

Hoyler, M. and Jöns, H. 2008. Kampf um Talente? Internationalisierung britischer Universitäten durch ausländische Wissenschaftler. Geographische Rundschau 60, no. 6: 60-64.

Institute of International Education. ed. (2005). Open doors: 1948-2004: report on international educational exchange: CD-ROM. New York: Institute of International Education.

Institute of International Education. ed. (2010). Open doors online: Report on international educational exchange. http://opendoors.iienetwork.org/, accessed on $7^{\text {th }}$ June 2010

Jansen, C. 2004. Exzellenz weltweit: die Alexander von Humboldt-Stiftung zwischen Wissenschaftsförderung und auswärtiger Kulturpolitik (1953-2003). Unter Mitarbeit von Christoph Nensa. Cologne: Dumont. 
Jöns, H. 2003a. Geographies of international scientific exchange in their political context. In Frontiers of geography, ed. J. Nemes Nagy and A. Jakobi, 227247. Budapest: Eötvos Loránd University.

Jöns, H. 2003b. Grenzüberschreitende Mobilität und Kooperation in den Wissenschaften. Heidelberg: University of Heidelberg.

Jöns, H. 2007. Transnational mobility and the spaces of knowledge production. Social Geography 2, no. 2: 97-114.

Jöns, H. 2009. 'Brain circulation' and transnational knowledge networks: studying long-term effects of academic mobility to Germany, 1954-2000. Global Networks 9, no. 3: 315-338.

Kulis, S. and Sicotte, D. 2002. Women scientists in academia: geographically constrained to big cities, college clusters, or the coasts? Research in Higher Education 43, no. 1: 1-30.

Latour, B. 1987. Science in action: how to follow scientists and engineers through society. Cambridge, MA: Harvard University Press.

Leemann, R.J. 2010. Gender inequalities in transnational academic mobility and the ideal type of academic entrepreneur. Discourse: Studies in the Cultural Politics of Education 31, no. 5: 605-625.

Loeb, J.W. 2006. The status of female faculty in the U.S.: thirty-five years with equal opportunity legislation. Management Revue 17, no. 2: 157-180.

Majcher, A. 2002. Gender inequality in German academia and strategies for change. German Policy Studies 2, no. 3.

Meusburger, P. and Schuch, T. 2010. From mediocrity and existential crisis to scientific excellence: Heidelberg University between 1803 and 1932. In 
Geographies of science, ed. P. Meusburger, D.N. Livingstone and H. Jöns, 5793. Dordrecht: Springer.

Meusburger, P., Livingstone, D.N. and Jöns, H. ed. 2010. Geographies of science. Dordrecht: Springer.

Morano-Foadi, S. 2005. Scientific mobility, career progression, and excellence in the European research area. International Migration 43, no. 5: 133-62.

Musselin, C. 2004. Towards a European academic labour market? Some lessons drawn from empirical studies on academic mobility. Higher Education 48, no. 1: $55-78$.

National Science Board. ed. 1998. Science and engineering indicators 1998. Arlington, VA: National Science Foundation.

National Science Board. ed. 2010. Science and engineering indicators 2010. Arlington, VA: National Science Foundation.

OECD. ed. 2009. Education at a glance 2009. Paris: OECD.

O'Hara, S. 2009. Internationalizing the academy: the impact of scholar mobility. In Higher education on the move: new developments in global mobility, ed. R. Bhandari and S. Laughlin, 29-47. New York: Institute of International Education.

Robertson, S.L. 2006. Brain drain, brain gain and brain circulation. Globalisation, Societies and Education 4, no. 1, 1-5.

Robertson, S.L. 2010. Critical response to special section: international academic mobility. Discourse: Studies in the Cultural Politics of Education 31, no. 5: 641-647. 
Scheibelhofer, E. 2008. Gender still matters: mobility aspirations among European scientists working abroad. In Gendered mobilities, ed. T.P. Uteng and T. Cresswell, 115-128. Aldershot: Ashgate.

Shauman, K.A. and Xie, Y. 1996. Geographic mobility of scientists: sex differences and family constraints. Demography 33, no. 4: 455-468.

Shaw, I.S., Leder, S. and Harris, B.J. 2007. Introduction: Women, tenure and promotion. NWSA Journal 19, no. 3: vii-viii.

Teichler, U. and Maiworm, F. 1997. The ERASMUS experience: major findings of the ERASMUS Evaluation Research Project. Brussels: CEC.

Traweek, S. 1988. Pilgrim's progress: male tales told during a life in physics. In The sciences studies reader, ed. M. Bagioli. 1999, 525-542. New York: Routledge.

Universities UK. ed. 2007. Talent wars: the international market for academic staff. London: Universities UK.

Universities UK. ed. 2008. Researcher mobility in the European Research Area: barriers and incentives. London: Universities UK.

Van de Sande, D., H. L. Ackers and B. Gill (2005) Impact assessment of the Marie Curie fellowships under the 4th and 5th framework programmes of research and technological development of the EU (1994-2002). Brussels: European Commission.

Welch, A.R. 1997. The peripatetic professor: the internationalisation of the academic profession. Higher Education 34, no. 1: 323-45.

Welch, A. 2008. Myths and modes of mobility: the changing face of academic mobility in the global era. In Students, staff and academic mobility in higher education, ed. M. Byram and F. Dervin, 292-311. Newcastle: Cambridge Scholars Publishing. 
Ward, K. and Wolf-Wendel, L. 2004. Academic motherhood: managing complex roles in research universities. The Review of Higher Education 27, no. 2: 233257.

Xie, Y. and Shauman, K.A. 1998. Sex differences in research productivity: new evidence about an old puzzle. American Sociological Review 63, no. 1: 847870.

Zuckerman, H. (1987). The careers of men and women scientists: A review of current research. In Women: their underrepresentation and career differentials in science and engineering, ed. L. S. Dix, 127-156. Washington, DC: National Academy Press.

Zuckerman, H., J.R. Cole and J.T. Bruer. ed. 1991. The outer circle: women in the scientific community. New York: Norton. 
Table 1. Key figures on postal survey among Humboldt research fellows 1981-2000

\begin{tabular}{|c|c|c|c|c|c|c|}
\hline & \multicolumn{2}{|c|}{$1981-2000$} & \multicolumn{2}{|c|}{$1981-1990$} & \multicolumn{2}{|c|}{ 1991-2000 } \\
\hline & abs & $\%$ & abs & $\%$ & abs & $\%$ \\
\hline \multicolumn{7}{|c|}{ A. Humboldt research fellows $(\mathrm{N})$} \\
\hline Male & 8,079 & 85.6 & 3,966 & 87.9 & 4,113 & 83.5 \\
\hline Female & 1,349 & 14.3 & 537 & 11.9 & 812 & 16.5 \\
\hline Unknown & 11 & 0.1 & 11 & 0.2 & 0 & 0.0 \\
\hline Total & 9,439 & 100 & 4,514 & 100 & 4,925 & 100.0 \\
\hline \multicolumn{7}{|c|}{ B. With postal address (sampling frame) } \\
\hline Male & 7,648 & 85.9 & 3,695 & 88.4 & 3,953 & 83.6 \\
\hline Female & 1,259 & 14.1 & 483 & 11.6 & 776 & 16.4 \\
\hline Unknown & 1 & 0.0 & 1 & 0.0 & 0 & 0.0 \\
\hline Total & 8,908 & 100 & 4,179 & 100 & 4,729 & 100.0 \\
\hline \multicolumn{7}{|c|}{ C. Survey sample } \\
\hline Male & 1,926 & 86.3 & 902 & 87.6 & 1,024 & 85.1 \\
\hline Female & 307 & 13.7 & 128 & 12.4 & 179 & 14.9 \\
\hline Total & 2,233 & 100 & 1,030 & 100 & 1,203 & 100.0 \\
\hline \multicolumn{7}{|c|}{ D. Responses (n) } \\
\hline Male & 989 & 87.4 & 427 & 86.1 & 562 & 88.5 \\
\hline Female & 142 & 12.6 & 69 & 13.9 & 73 & 11.5 \\
\hline Total & 1,131 & 100.0 & 496 & 100.0 & 635 & 100.0 \\
\hline
\end{tabular}

Source: Database of the Humboldt Foundation and own postal survey 2003. 
Table 2. Academic interaction and productivity during Humboldt research stays (in \% of Humboldt research fellows 1981-2000).

\begin{tabular}{|c|c|c|c|}
\hline Topic & Men & Women & Total \\
\hline \multicolumn{4}{|l|}{ A. Scientific interaction at the host institution ${ }^{\text {ns }}$} \\
\hline \multirow{2}{*}{$\begin{array}{l}\text { a. No or hardly any exchange of information } \\
\text { b. Occasional exchange of information }\end{array}$} & 0.3 & 0.0 & 0.3 \\
\hline & 2.9 & 3.5 & 3.0 \\
\hline c. Intensive exchange of information & 7.4 & 7.1 & 7.4 \\
\hline d. Concentration on own research projects & 32.4 & 31.2 & 32.2 \\
\hline e. Participation in ongoing research project & 14.9 & 14.2 & 14.8 \\
\hline f. Problem-oriented collaboration & 16.5 & 17.7 & 16.7 \\
\hline g. Continued project collaboration & 25.6 & 26.2 & 25.7 \\
\hline Sample size (n) & 973 & 141 & 1,114 \\
\hline \multicolumn{4}{|l|}{ B. Integration into research ${ }^{\text {ns }}$} \\
\hline a. $1=$ Not at all & 1.2 & 1.4 & 1.2 \\
\hline b. 2 & 4.7 & 4.2 & 4.6 \\
\hline c. 3 & 12.9 & 16.2 & 13.4 \\
\hline \multirow{2}{*}{$\begin{array}{l}\text { d. } 4 \\
\text { e. } 5=\text { Very well }\end{array}$} & 30.5 & 31.7 & 30.6 \\
\hline & 50.7 & 46.5 & 50.1 \\
\hline Sample size (n) & 981 & 142 & 1,123 \\
\hline \multicolumn{4}{|l|}{ C. Integration into teaching ${ }^{\text {ns }}$} \\
\hline a. $1=$ not at all & 51.9 & 52.7 & 52.0 \\
\hline b. 2 & 21.3 & 15.5 & 20.6 \\
\hline c. 3 & 12.7 & 12.4 & 12.7 \\
\hline \multirow{2}{*}{$\begin{array}{l}\text { d. } 4 \\
\text { e. } 5=\text { very well }\end{array}$} & 8.0 & 11.6 & 8.5 \\
\hline & 6.1 & 7.8 & 6.3 \\
\hline Sample size (n) & 888 & 129 & 1,017 \\
\hline \multicolumn{4}{|l|}{ D. Resulting publications ${ }^{\mathrm{ns}}$} \\
\hline a. No & 3.0 & 1.4 & 2.8 \\
\hline b. Yes, as a single author & 20.1 & 27.7 & 21.1 \\
\hline $\begin{array}{l}\text { c. Yes, as a single author and/or in collaboration } \\
\text { with researchers outside Germany }\end{array}$ & 5.4 & 5.7 & 5.4 \\
\hline $\begin{array}{l}\text { d. Yes, also in collaboration with researchers in } \\
\text { Germany }\end{array}$ & 71.4 & 65.2 & 70.7 \\
\hline Sample size (n) & 984 & 141 & 1,125 \\
\hline \multicolumn{4}{|l|}{$\begin{array}{l}\text { E. Resulting events organized with researchers in } \\
\text { Germany }^{\text {ns }}\end{array}$} \\
\hline a. No & 66.2 & 70.0 & 66.6 \\
\hline b. Yes, one event & 15.0 & 15.7 & 15.1 \\
\hline c. Yes, more than one event & 18.9 & 14.3 & 18.3 \\
\hline Sample size (n) & 981 & 140 & 1,121 \\
\hline Total sample size (n) & 989 & 142 & 1,131 \\
\hline
\end{tabular}

Statistically significant gender differences:

$\mathrm{ns}=$ not on $5 \%$ level, $*=$ on $5 \%$ level, $* *=$ on $1 \%$ level, $* * *=$ on $0.1 \%$ level.

Source: Own postal survey 2003. 
Table 3. Long-term effects of academic mobility to Germany (in \% of Humboldt research fellows 1981-2000).

\begin{tabular}{|c|c|c|c|}
\hline Topic & Men & Women & Total \\
\hline \multicolumn{4}{|l|}{$\begin{array}{l}\text { A. Continued scientific interaction } \\
\text { - In total }\end{array}$} \\
\hline a. No further contact & 3.2 & 5.7 & 3.5 \\
\hline b. Occasional exchange of information & 22.4 & 22.9 & 22.5 \\
\hline c. Regular exchange of information & 13.2 & 16.4 & 13.6 \\
\hline d. One single collaboration after stay & 3.6 & 4.3 & 3.7 \\
\hline e. Occasional collaboration & 22.1 & 20.7 & 22.0 \\
\hline f. Regular collaboration & 35.5 & 30.0 & 34.8 \\
\hline Sample size (n) & 980 & 140 & 1,120 \\
\hline - Natural sciences ${ }^{* *}$ & & & \\
\hline a. No further contact & 3.2 & 9.5 & 2.3 \\
\hline b. Occasional exchange of information & 21.5 & 25.7 & 23.5 \\
\hline c. Regular exchange of information & 11.9 & 16.2 & 16.8 \\
\hline d. One single collaboration after stay & 3.9 & 8.1 & 1.7 \\
\hline e. Occasional collaboration & 21.7 & 16.2 & 22.8 \\
\hline f. Regular collaboration & 37.9 & 24.3 & 32.9 \\
\hline Sample size (n) & 623 & 74 & 697 \\
\hline - Social sciences and humanities ${ }^{\text {ns }}$ & & & \\
\hline a. No further contact & 3.0 & 0.0 & 3.9 \\
\hline b. Occasional exchange of information & 24.2 & 21.0 & 22.0 \\
\hline c. Regular exchange of information & 16.5 & 17.7 & 12.3 \\
\hline d. One single collaboration after stay & 2.1 & 0.0 & 4.3 \\
\hline e. Occasional collaboration & 21.6 & 27.4 & 21.1 \\
\hline f. Regular collaboration & 32.6 & 33.9 & 36.4 \\
\hline Sample size (n) & 236 & 62 & 298 \\
\hline - $1981-1990^{\mathrm{ns}}$ & & & \\
\hline a. No further contact & 4.0 & 7.2 & 4.5 \\
\hline b. Occasional exchange of information & 22.9 & 18.8 & 22.4 \\
\hline c. Regular exchange of information & 10.2 & 20.3 & 11.6 \\
\hline d. One single collaboration after stay & 3.8 & 5.8 & 4.1 \\
\hline e. Occasional collaboration & 25.1 & 18.8 & 24.2 \\
\hline f. Regular collaboration & 34.0 & 29.0 & 33.3 \\
\hline Sample size (n) & 423 & 69 & 492 \\
\hline - $1991-2000^{\mathrm{ns}}$ & & & \\
\hline a. No further contact & 2.5 & 4.2 & 2.7 \\
\hline b. Occasional exchange of information & 22.1 & 26.8 & 22.6 \\
\hline c. Regular exchange of information & 15.4 & 12.7 & 15.1 \\
\hline d. One single collaboration after stay & 3.4 & 2.8 & 3.3 \\
\hline e. Occasional collaboration & 19.9 & 22.5 & 20.2 \\
\hline f. Regular collaboration & 36.6 & 31.0 & 36.0 \\
\hline Sample size (n) & 557 & 71 & 628 \\
\hline - By themselves ${ }^{*}$ & & & \\
\hline a. No further contact & 4.1 & 11.6 & 5.6 \\
\hline b. Occasional exchange of information & 23.0 & 24.6 & 23.4 \\
\hline c. Regular exchange of information & 15.2 & 18.8 & 16.0 \\
\hline d. One single collaboration after stay & 2.2 & 5.8 & 3.0 \\
\hline e. Occasional collaboration & 17.8 & 18.8 & 18.0 \\
\hline f. Regular collaboration & 37.5 & 20.3 & 34.0 \\
\hline Sample size (n) & 269 & 69 & 338 \\
\hline Total sample size $(\mathrm{n})$ & 989 & 142 & 1,131 \\
\hline
\end{tabular}

Statistically significant gender differences:

$\mathrm{ns}=$ not on $5 \%$ level, $*=$ on $5 \%$ level, $* *=$ on $1 \%$ level, $* * *=$ on $0.1 \%$ level.

Source: Own postal survey 2003. 
Table 4. Evaluation of research work in Germany and return visits (in \% of Humboldt research fellows 1981-2000).

\begin{tabular}{|c|c|c|c|}
\hline $\begin{array}{c}\text { Topic } \\
\text { Importance of ctav for } 0 \text { re research work }\end{array}$ & Men & Women & Total \\
\hline \multicolumn{4}{|l|}{$\begin{array}{l}\text { A. Importance of stay for own research work } \\
\text { - In total }\end{array}$} \\
\hline a. $1+2=$ no and low importance & 1.6 & 3.5 & 1.9 \\
\hline b. 3 & 7.9 & 6.3 & 7.7 \\
\hline c. $4+5=$ high and maximum importance & 90.4 & 90.1 & 90.4 \\
\hline Sample size (n) & 982 & 142 & 1124 \\
\hline - Natural sciences* & & & \\
\hline a. $1+2=$ no and low importance & 1.8 & 6.7 & 2.3 \\
\hline b. 3 & 8.5 & 9.3 & 8.6 \\
\hline c. $4+5=$ high and maximum importance & 89.7 & 84.0 & 89.1 \\
\hline Sample size (n) & 621 & 75 & 620 \\
\hline - Social sciences and humanities ${ }^{\mathrm{ns}}$ & & & \\
\hline a. $1+2=$ no and low importance & 1.7 & 0.0 & 1.3 \\
\hline b. 3 & 5.1 & 3.2 & 4.7 \\
\hline c. $4+5=$ high and maximum importance & 93.2 & 96.8 & 94.0 \\
\hline Sample size (n) & 237 & 63 & 300 \\
\hline - $1981-1990^{* *}$ & & & \\
\hline a. $1+2=$ no and low importance & 0.9 & 5.8 & 1.6 \\
\hline b. 3 & 10.2 & 5.8 & 9.6 \\
\hline c. $4+5=$ high and maximum importance & 88.9 & 88.4 & 88.8 \\
\hline Sample size (n) & 423 & 69 & 437 \\
\hline - $1991-2000^{\mathrm{ns}}$ & & & \\
\hline a. $1+2=$ no and low importance & 2.1 & 1.4 & 2.1 \\
\hline b. 3 & 6.3 & 6.8 & 6.3 \\
\hline c. $4+5=$ high and maximum importance & 91.6 & 91.8 & 91.6 \\
\hline Sample size (n) & 559 & 73 & 632 \\
\hline - By themselves* & & & \\
\hline a. $1+2=$ no and low importance & 1.5 & 7.0 & 2.6 \\
\hline b. 3 & 9.9 & 5.6 & 9.0 \\
\hline c. $4+5=$ high and maximum importance & 88.6 & 87.3 & 88.4 \\
\hline Sample size (n) & 273 & 71 & 344 \\
\hline B. Return visits (over one month) & & & \\
\hline - In total ${ }^{\mathrm{ns}}$ & 45.7 & 39.1 & 44.9 \\
\hline - Natural sciences ${ }^{*}$ & 43.6 & 31.5 & 42.3 \\
\hline - Social sciences and humanities ${ }^{\mathrm{ns}}$ & 52.8 & 45.9 & 51.4 \\
\hline - $1981-1990^{\mathrm{ns}}$ & 53.3 & 51.5 & 53.1 \\
\hline - 1991-2000* & 39.9 & 27.1 & 38.4 \\
\hline - By themselves ${ }^{\text {ns }}$ & 43.0 & 33.3 & 41.0 \\
\hline - With partner ${ }^{\text {ns }}$ & 46.8 & 29.2 & 44.4 \\
\hline - With family ${ }^{\text {ns }}$ & 46.7 & 59.4 & 47.4 \\
\hline Total sample size (n) & 989 & 142 & 1,131 \\
\hline
\end{tabular}

Statistically significant gender differences:

$\mathrm{ns}=$ not on $5 \%$ level, $*=$ on $5 \%$ level, $* *=$ on $1 \%$ level, $* * *=$ on $0.1 \%$ level.

Source: Own postal survey 2003. 


\section{Figure 1}

Gender relations in higher education by career stage and selected country, 1997 and 2007.

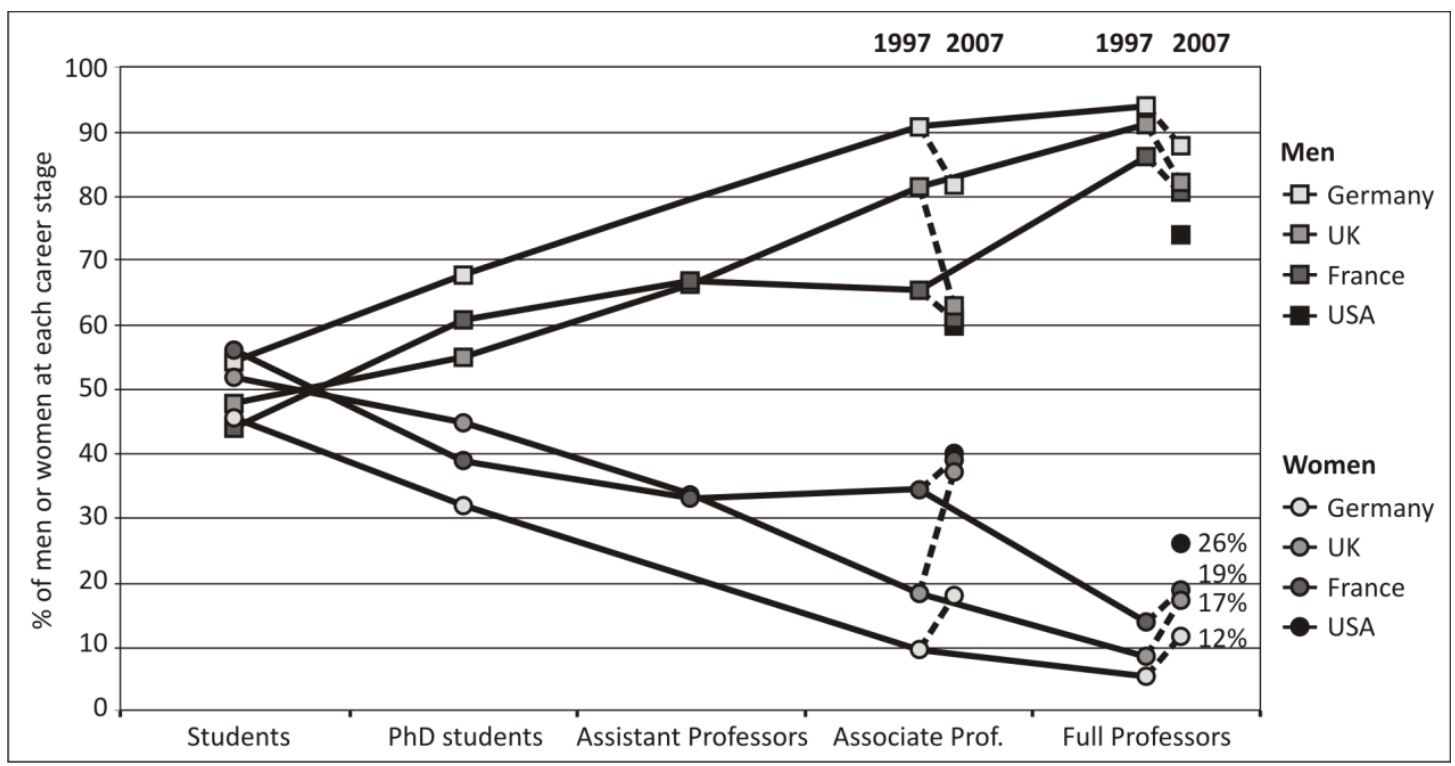

Source: European Commission 2000: 13; European Commission 2009: 75; U.S.

Department of Education 2008: Table 250. 


\section{Figure 2}

Academic mobility to the United States, 1980/81-2008/09.

a) International students

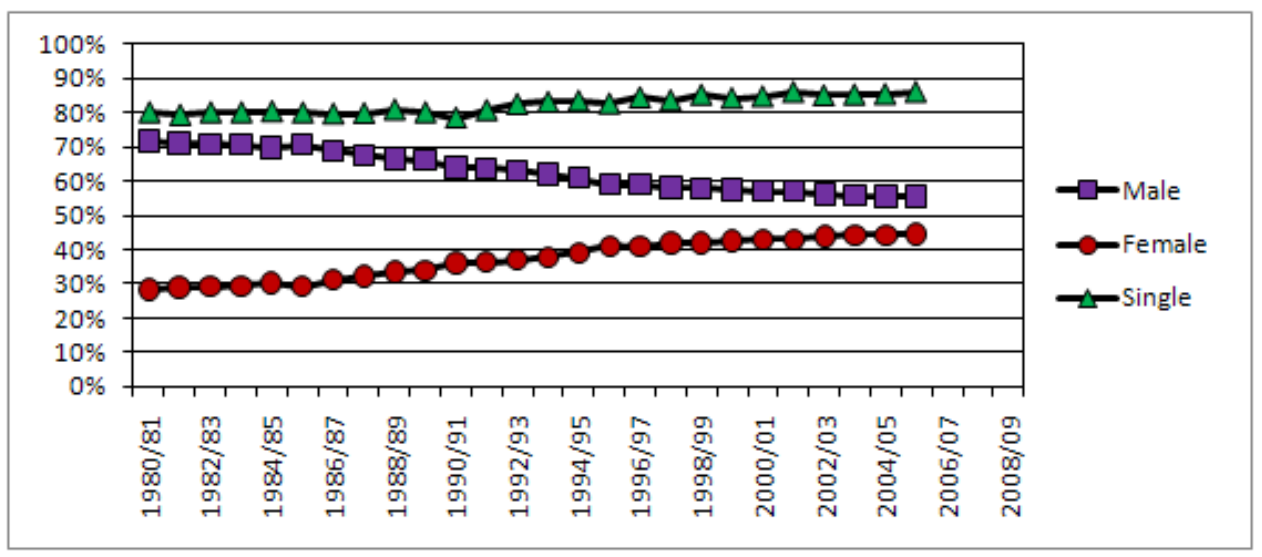

b) International scholars

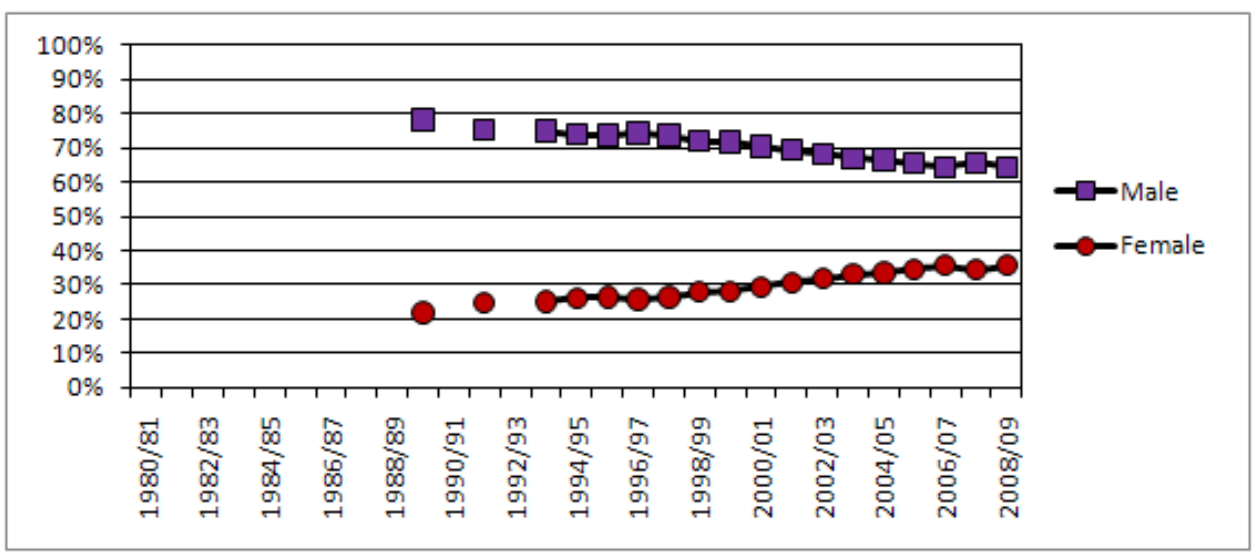

Source: Institute of International Education 2005; 2010. 


\section{Figure 3}

Gender relations among Humboldt research fellows in Germany, 1981-2000.

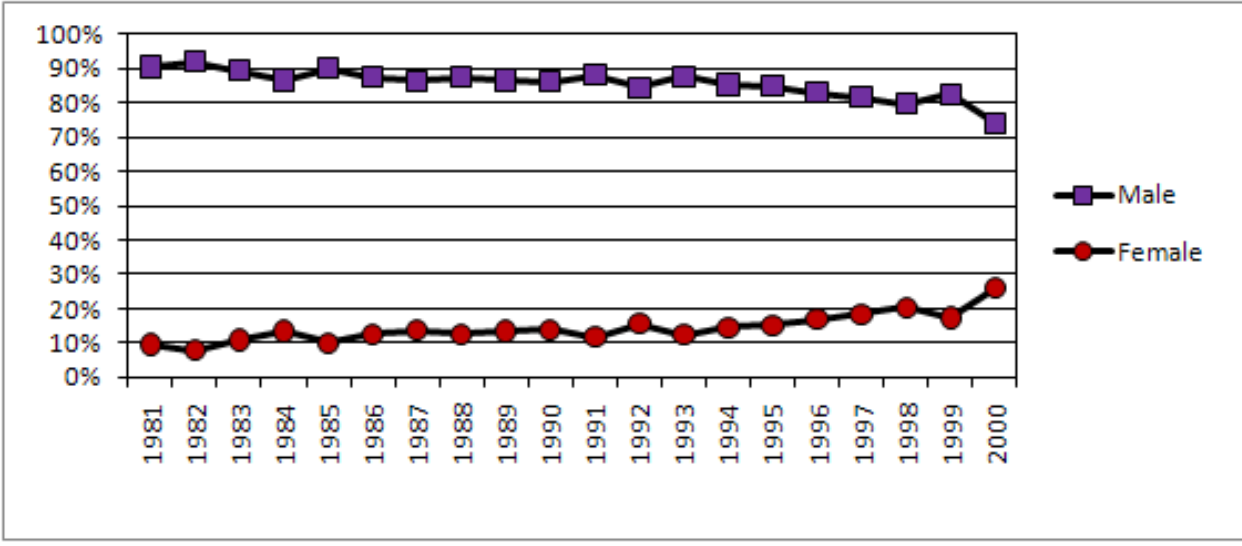

Source: Database of the Humboldt Foundation. 


\section{Figure 4}

Type of entourage for a long-term research stay in Germany.

a) Humboldt research fellows, 1981-1990

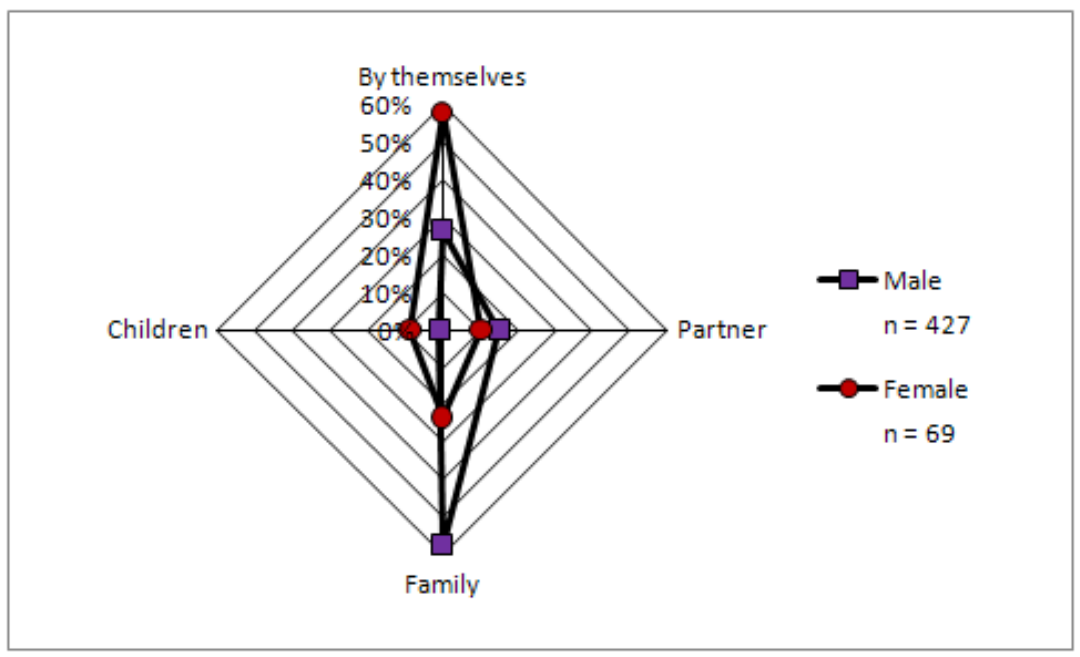

b) Humboldt research fellows, 1991-2000

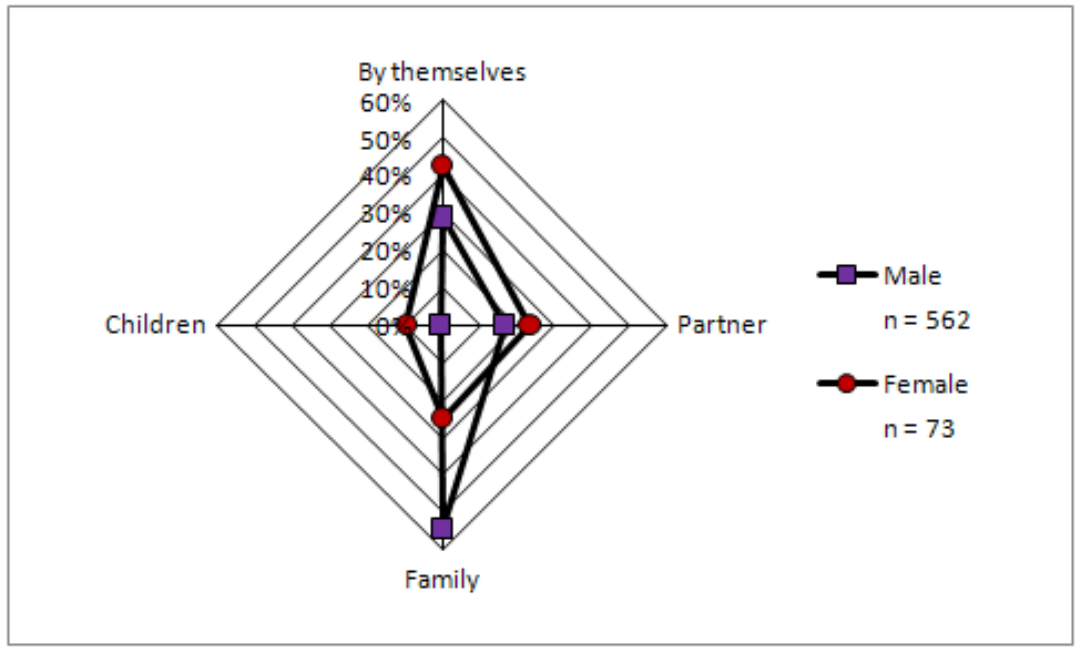

Source: Database of the Humboldt Foundation. 
Figure 5

Humboldt research fellows 1992-2001 by source country and gender.

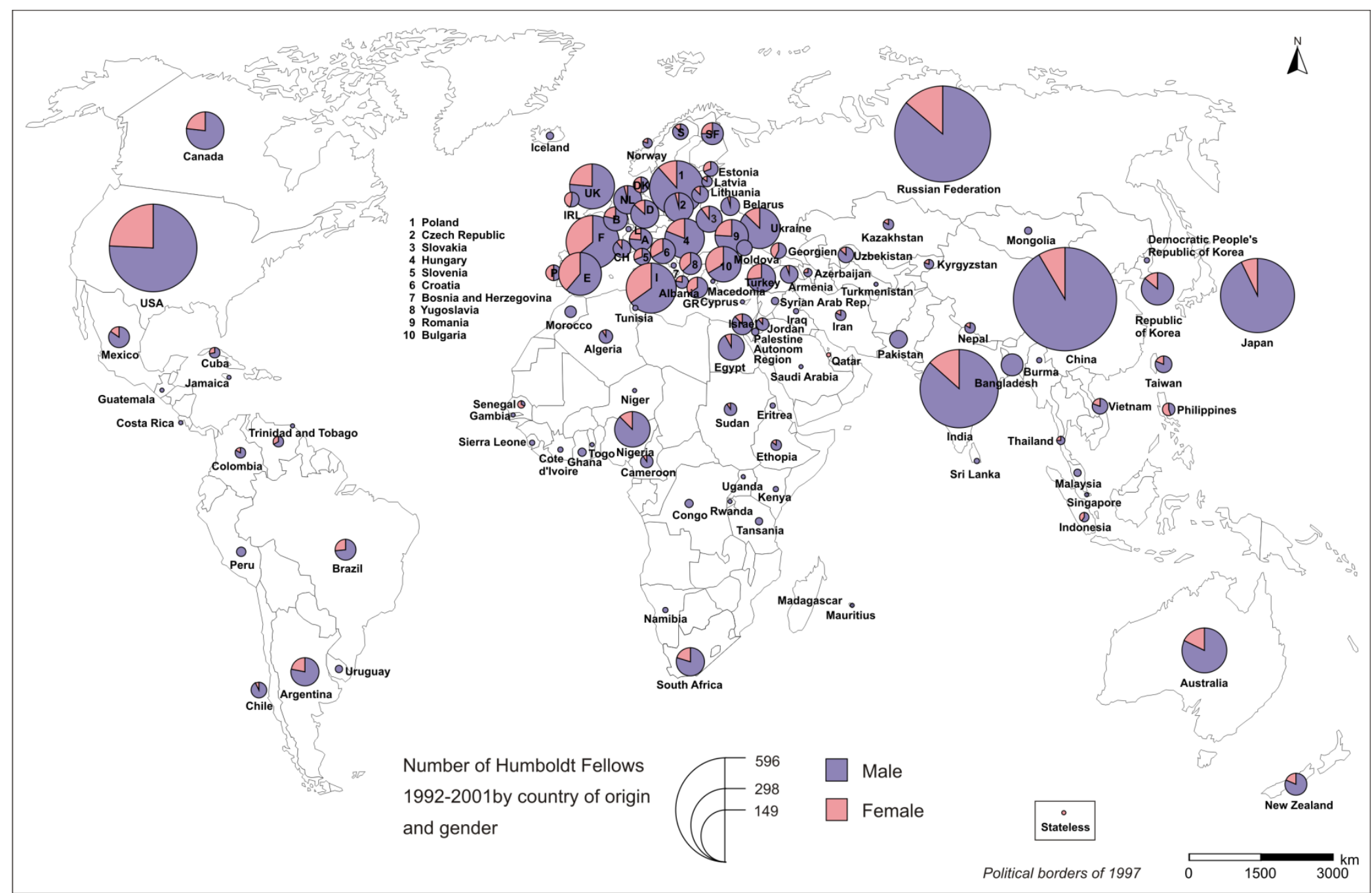

Source: Database of the Humboldt Foundation. 


\section{Figure 6}

The share of women in academic mobility to Germany, in US higher education, and in German higher education by decade.

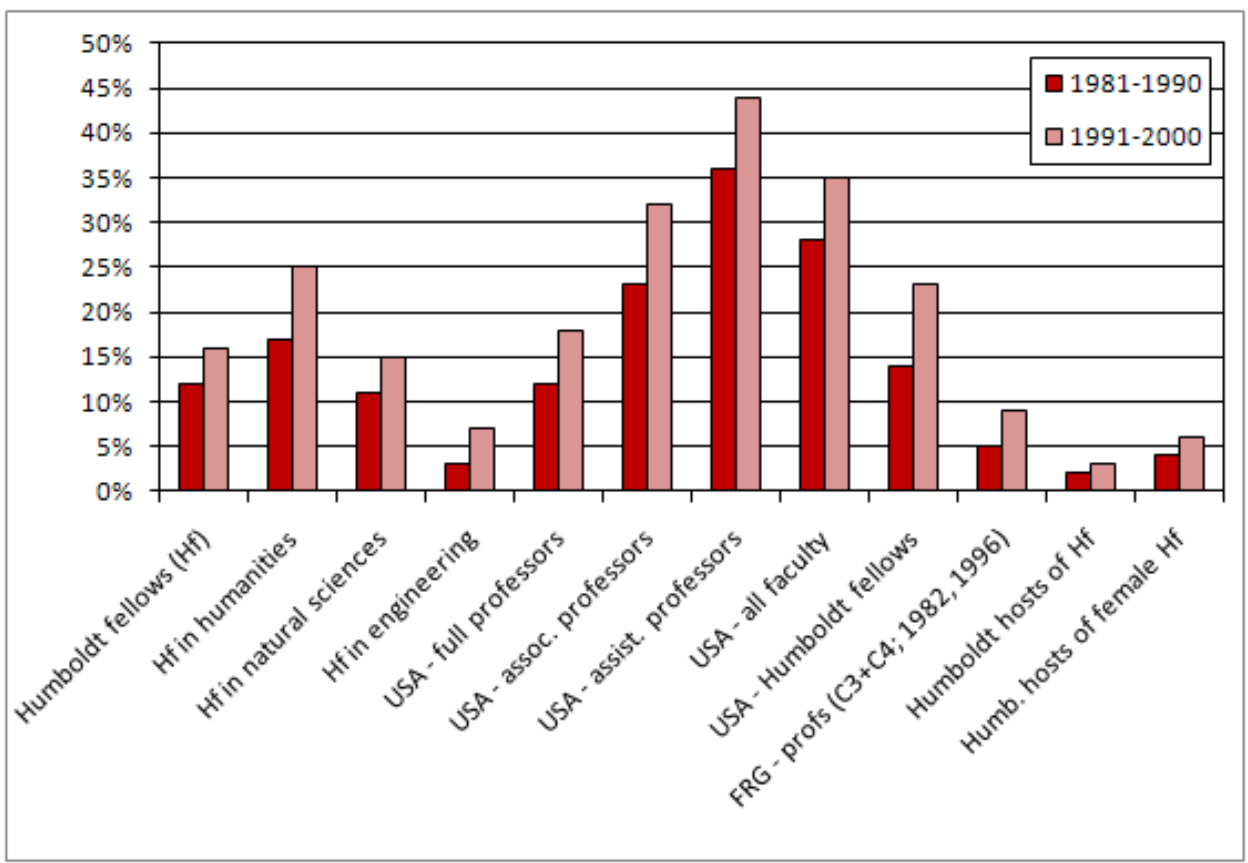

Source: Database of the Humboldt Foundation; NSF WebCASPAR Database System; Statistisches Bundesamt 1982, 1998. 